\title{
Minireview
}

\section{Drug Discovery Strategies for SARS-CoV-2}

\author{
Zeenat A. Shyr, Kirill Gorshkov, Catherine Z. Chen, and Wei Zheng \\ National Center for Advancing Translational Sciences, National Institutes of Health, Bethesda, Maryland \\ Received May 21, 2020; accepted July 10, 2020
}

\begin{abstract}
Coronavirus disease 2019 (COVID-19) is a novel disease caused by the severe acute respiratory syndrome coronavirus (SARS-CoV)-2 virus that was first detected in December of 2019 in Wuhan, China, and has rapidly spread worldwide. The search for a suitable vaccine as well as effective therapeutics for the treatment of COVID-19 is underway. Drug repurposing screens provide a useful and effective solution for identifying potential therapeutics against SARS-CoV-2. For example, the experimental drug remdesivir, originally developed for Ebola virus infections, has been approved by the US Food and Drug Administration as an emergency use treatment of COVID-19. However, the efficacy and toxicity of this drug need further improvements. In this review, we discuss recent findings on the pathology of coronaviruses and the drug targets for the
\end{abstract}

\section{Introduction}

Coronaviruses are enveloped, single-stranded, positivesensed RNA viruses belonging to the family Coronaviridae with genomes ranging from 26 to $32 \mathrm{~kb}$ in length. Several known strains of coronaviruses such as OC43, HKU, 229E5, and NL63 are pathogenic to humans and associated with mild common cold symptoms (D. E. Gordon et al., preprint, DOI: https://doi.org/10.1101/2020.03.22.002386). However, in the past two decades, three notable coronaviruses of the pandemic scale have emerged and produced severe clinical symptoms, including acute respiratory distress syndrome (ARDS). In 2002, the coronavirus strain SARS-CoV, named for causing severe acute respiratory syndrome (SARS), originated in the Guangdong province of China (Drosten et al., 2003). In 2012, another coronavirus with reported clinical similarity to SARS$\mathrm{CoV}$ was first detected in Saudi Arabia and later identified as

This work was supported by the Intramural Research Programs of the National Center for Advancing Translational Sciences of National Institutes of Health (Grants ZIA-TR000018-01 and ZIA TR000422).

https://doi.org/10.1124/jpet.120.000123. treatment of COVID-19. Both SARS-CoV-2-specific inhibitors and broad-spectrum anticoronavirus drugs against SARS-CoV, Middle East respiratory syndrome coronavirus, and SARS-CoV-2 will be valuable additions to the anti-SARS-CoV-2 armament. A multitarget treatment approach with synergistic drug combinations containing different mechanisms of action may be a practical therapeutic strategy for the treatment of severe COVID-19.

\section{SIGNIFICANCE STATEMENT}

Understanding the biology and pathology of RNA viruses is critical to accomplish the challenging task of developing vaccines and therapeutics against SARS-CoV-2. This review highlights the anti-SARS-CoV-2 drug targets and therapeutic development strategies for COVID-19 treatment.

ABBREVIATIONS: ACE, angiotensin converting enzyme; ADE, antibody-dependent enhancement; ARDS, acute respiratory distress syndrome; BSL, biosafety level; 3CLpro, 3C-like serine protease; COVID-19, coronavirus disease 2019; CQ, chloroquine; EBOV, Ebola virus; EndoU, uridinespecific endoribonuclease; FDA, US Food and Drug Administration; HIV, human immunodeficiency virus; HCQ, hydroxychloroquine; IL-6, interleukin-6; MERS-CoV, Middle East respiratory syndrome coronavirus; NSP, nonstructural protein; RBD, receptor-binding domain; RdRp, RNAdependent RNA polymerase; SARS, severe acute respiratory syndrome; SARS-CoV, severe acute respiratory syndrome coronavirus; TMPRSS2, transmembrane protease serine type 2. 
SARS-CoV and MERS-CoV infections, ARDS can be induced in severe cases of COVID-19. ARDS is largely mediated through the significant release of proinflammatory cytokines that results in a cytokine storm, which likely triggers multiorgan failure and contributes to increased death rates (Li et al., 2020). Dependent on several factors such as preexisting conditions and the immune response, severe disease can precipitate pathophysiological effects on the heart, kidney, liver, and central nervous system. Examples include myocardial injury, arrhythmias, increased risk of myocardial infarction, liver dysfunction, kidney failure, neurologic complications such as ataxia, seizures, neuralgia, acute cerebrovascular disease, and encephalopathy (see Zaim et al. (2020) for an in depth review). In addition, SARS$\mathrm{CoV}-2$ may have tropism toward tissues other than the lungs, which could contribute to disease exacerbation (Puelles et al., 2020).

Genome sequencing and phylogenetic analyses have confirmed that SARS-CoV, MERS-CoV, and SARS-CoV-2 are all zoonotic diseases that originated from bat coronaviruses leading to infections in humans either directly or indirectly through an intermediate host (Lu et al., 2020). Unfortunately, predicting the zoonotic potential of newly detected viruses has been severely hindered by a lack of functional data for viral sequences in these animals (Letko et al., 2020). Unlike SARS-CoV or MERS-CoV, where transmissions mainly occur in a nosocomial manner, SARS-CoV-2 appears to spread more efficiently, as viral shedding may also occur in asymptomatic individuals prior to the onset of symptoms. Asymptomatic transmission increases its pandemic potential severalfold (Tu et al., 2020). Indeed, COVID-19 was declared a pandemic by the World Health Organization on March 11, 2020, because there was a dramatic and exponential increase in the number of cases and deaths associated with the disease within several months. Currently, close to the end of June 2020, there are over 10 million cases worldwide with over 500,000 deaths. Treatment options for COVID-19 are limited while several vaccines against SARS-CoV-2 are in the works. On April 29, 2020, the US National Institutes of Health announced that remdesivir, an experimental drug originally developed as an RNA-dependent RNA polymerase (RdRP) inhibitor against Ebola virus (EBOV), showed positive efficacy in a clinical phase 3 trial for COVID-19. Hospitalized patients with COVID-19 treated with remdesivir shortened the time to recovery by $31 \%$ (from 15 to 11 days). On May 1 , 2020, the US Food and Drug Administration (FDA) granted emergency use authorization of remdesivir for treatment of COVID-19, while a formal approval is still pending.

\section{Overview of SARS-CoV-2 Genome and Protein Constituents}

SARS-CoV, MERS-CoV, and SARS-CoV-2 belong to the Betacoronavirus genus, whose genomes typically contain $5^{\prime}$ methylated caps at the $\mathrm{N}$ terminus and a $3^{\prime}$-poly-A tail at the $\mathrm{C}$ terminus with a highly conserved order of genes related to replication/transcription and structural components. The replication and transcription-related gene is translated into two large nonstructural polyproteins by two distinct but overlapping open reading frames translated by ribosomal frameshifting (Tu et al., 2020). The overlapping open reading frame, composing two-thirds of the coronavirus genome, encodes the large replicase polyproteins $1 \mathrm{a}$ and $1 \mathrm{~b}$, which are cleaved by papain-like cysteine protease and 3C-like serine protease (3CLpro, also called Mpro). This cleavage produces 16 nonstructural proteins (NSPs) including important enzymes involved in the transcription and replication of coronaviruses such as RdRP, helicase (Nsp13), and exonuclease (Nsp14) (Tang et al., 2020). The 3' one-third of the coronavirus genome is translated from subgenomic RNAs and encodes the structural proteins spike (S), envelope (E), and membrane (M) that constitute the viral coat and the nucleocapsid $(\mathrm{N})$ protein that packages the viral genome (Tu et al., 2020). These structural proteins are essential for virus-host cell binding and virus assembly. Upon translation, the S, E, and M structural proteins are inserted into the rough endoplasmic reticulum to travel along the secretory pathway to the endoplasmic reticulum-Golgi apparatus intermediate compartment or coronavirus particle assembly and subsequent release from the cell via exocytosis (Tang et al., 2020).

\section{Viral Entry Through the Binding of SARS-CoV-2 Spike Proteins to Angiotensin Converting Enzyme 2 Receptor}

The S proteins of SARS-CoV, required for viral entry into the host target cell, are synthesized as inactive precursors and become activated only upon proteolysis (Gierer et al., 2013). The S protein has two functional domains called $\mathrm{S} 1$ and $\mathrm{S} 2$. S1 contains an $\mathrm{N}$-terminal domain and a receptor-binding domain (RBD). The receptor-binding motif (RBM) is located within the carboxy-terminal half of the RBD and contains residues that enable attachment of the $\mathrm{S}$ protein to a host cell receptor (Letko et al., 2020). The S2 subunit drives the fusion of viral and host membrane subsequent to cleavage, or "priming," by cellular proteases. SARS-CoV is known to gain entry into permissive host cells through interactions of the SARS-CoV S protein RBD with the cell surface receptor angiotensin converting enzyme (ACE) 2 (Wang et al., 2008). ACE2 is a negative regulator of the renin-angiotensin system and counterbalances the function of $\mathrm{ACE}$, thereby maintaining blood pressure homeostasis (Kuba et al., 2005). It was shown in animal models that ACE2 promotes anti-inflammation, antifibrosis, and vasodilation, whereas ACE promotes proinflammation, fibrosis, vasoconstriction, and severe lung injury (Kuba et al., 2005). Furthermore, through S protein binding, SARS-CoV downregulates ACE2 receptor, and therefore this process not only leads to viral entry but also potentially contributes to severe lung injury, as the ACE2 pathway has protective functions in many organs. Since $83 \%$ of ACE2expressing cells are alveolar epithelial type II cells and these cells contain high levels of multiple viral process-related genes, including regulatory genes for viral processes, viral life cycle, viral assembly, and viral genome replication, they can facilitate coronaviral replication in the lung (Y. Zhao et al., preprint, DOI: https://doi.org/10.1101/2020.01.26.919985). Sequence analysis showed that SARS-CoV-2 genome is very similar to SARS-CoV with a only a few differences in their complement of $3^{\prime}$ open reading frames that do not encode structural proteins (D. E. Gordon et al., preprint, DOI: https:// doi.org/10.1101/2020.03.22.002386). Specifically, the S proteins of SARS-CoV-2 and SARS-CoV share $76.5 \%$ identity in amino acid sequences and have a high degree of homology (Xu et al., 2020b). SARS-CoV-2 also uses ACE2 as a cellular entry receptor because, in cells that are otherwise not susceptible 
to SARS-CoV-2 infection, overexpressing human or bat ACE2 mediates SARS-CoV-2 infection and replication (Hoffmann et al., 2020a; Zhou et al., 2020). In addition, SARS-CoV-2 does not use other receptors such as dipeptidyl peptidase 4 , used by MERS-CoV, or the human aminopeptidase $\mathrm{N}$ used by human coronavirus strain 229E (Ou et al., 2020; Zhou et al., 2020). Several groups have now identified the RBD in SARS-CoV-2 and have confirmed by biochemical analyses as well as crystal structure prediction analyses that this domain binds strongly to both human and bat ACE2 receptor with a binding affinity significantly higher than that of SARS-CoV to the ACE2 receptor (Tai et al., 2020; Wan et al., 2020; Wrapp et al., 2020; $\mathrm{Xu}$ et al., 2020b). There has been much speculation that the high affinity binding of SARS-CoV-2 to ACE2 could mediate the increased potential for transmissibility and severity of infection. For instance, the coronavirus strain NL63 also uses the same ACE2 receptor for entry into the host cell as SARS-CoV, but the virus entry and outcome are vastly different, with SARS resulting in severe respiratory distress and NL63 resulting in only a mild respiratory infection (Mathewson et al., 2008). This led the authors to suggest that a lower-affinity interaction with NL63 for ACE2 may partially explain the different pathologic consequences of infection. It has been speculated that in addition to the ACE2 receptor, SARS-CoV-2 could employ other receptors for host cell entry. For example, the S protein of SARS-CoV-2 has a conserved RGD motif known to bind integrins, which is not found in other coronaviruses (Sigrist et al., 2020). This motif lies within the RBD of the S proteins of SARS-CoV-2, close to the ACE2 receptorbinding region (Sigrist et al., 2020). SARS-CoV-2 S protein can also interact with sialic acid receptors of the cells in the upper airways similar to MERS-CoV (E. Milanetti et al., preprint, DOI: https://doi.org/10.1101/2020.03.24.006197). Although the functional importance of integrins or sialic acid receptors in mediating SARS-CoV-2 S protein entry remains to be determined, these may potentially increase cell tropism, viral pathogenicity, and transmission of SARS-CoV-2.

\section{SARS-CoV-2 Has Multiple Viral Entry Mechanisms}

In general, coronaviruses deliver their genomes to the host cytosol by two known methods: directly fusing with the plasma membrane at the cell surface in a $\mathrm{pH}$-independent manner or utilizing the host cell's endocytic machinery in which the endocytosed virions are subjected to an activation step in the endosome. Endocytic activation is typically mediated by the acidic endosomal $\mathrm{pH}$, resulting in the fusion of the viral and endosomal membranes and release of the viral genome into the cytosol (Wang et al., 2008). Fusion with the cell membrane requires that the $\mathrm{S} 2$ domain of the $\mathrm{S}$ protein be primed by cellular proteases at the S' site. SARS-CoV is known to be able to enter host cells by directly fusing with the host membrane as well as through the endosomal pathway via cathepsin B and L (Matsuyama et al., 2010). SARS-CoV can also use the cell surface protease transmembrane protease serine type 2 (TMPRSS2) that belongs to the type II transmembrane serine protease family. Although SARS-CoV utilizes both host cell entry pathways, it appears that the TMPRSS2 pathway is the major route of infection of SARS-CoV in the lungs. However, in the absence of TMPRSS2,
SARS-CoV can also employ the endosomal late entry route for infection, as SARS-CoV viral spread is still detected in the alveoli of TMPRSS2 knockout mice (Iwata-Yoshikawa et al., 2019). Unlike other soluble serine proteases, TMPRSS2 is anchored on the plasma membrane and localized with ACE2 receptors on the surface of airway epithelial cells (Shulla et al., 2011). This colocalization makes the lungs particularly susceptible to infection. TMPRSS2 cleavage of S protein might also promote viral spread and pathogenesis by diminishing viral recognition by neutralizing antibodies. The cleavage of $\mathrm{S}$ protein can result in shedding of SARS S protein fragments that could act as antibody decoys (Glowacka et al., 2011). Although TMPRSS2 affects the entry of virus but not the other phases of virus replication, only a small amount of $\mathrm{S}$ protein needs to be cleaved to enable viral or cell-cell membrane fusion, even when minute or undetectable amounts of ACE2 is available (Shulla et al., 2011). In keeping with this, the expression and distribution of TMPRSS2, but not ACE2, correlates with SARS-CoV infection in the lungs. SARS-CoV studies have shown that TMPRSS2 cleaves the S protein after receptor binding, which causes conformational changes that expose the S' cleavage site (Glowacka et al., 2011). This confers a great advantage to the viral protein by protecting the activating cleavage site from premature proteolysis and yet ensuring that efficient cleavage occurs upon binding to the receptor on target cells (Shulla et al., 2011). Similarly, in the case of SARS-CoV-2, the host cell TMPRSS2 primes the S protein and enhances entry and infection (Hoffmann et al., 2020a; Matsuyama et al., 2020). SARS-CoV-2 may also use other host proteases such as trypsin for $\mathrm{S}$ protein activation (Ou et al., 2020). Similar to SARS-CoV, SARS-CoV-2 can also enter host cells through the endosomal pathway via cathepsins (Hoffmann et al., 2020a; Ou et al., 2020). Unlike SARS$\mathrm{CoV}$, the S protein of SARS-CoV-2 has a furin cleavage site at the S1/S2 boundary similar to MERS-CoV (Hoffmann et al., 2020a; Walls et al., 2020), which likely sensitizes S proteins to the subsequent activating proteolysis occurring on susceptible target cells, facilitates virus entry and infection, and potentially increases viral transmissibility (Qing and Gallagher, 2020). Since SARS-CoV-2 can be activated by an extensive range of proteases, and given that a varied number of proteases exist on the cell surface of different cell types, SARS-CoV-2 has the capacity to infect a wide range of cells (Tang et al., 2020). Thus, it is an opportunistic virus that can use multiple pathways of host cell entry and infection. It is conceivable that successful treatment of COVID-19 may require a cocktail of drugs that target multiple mechanisms of action as historically seen for the treatment of human immunodeficiency virus (HIV) infection; see the review by Maeda et al. (2019).

\section{Drug Development Strategies}

For negative-sense RNA viruses, approved therapies are currently available only for rabies virus, respiratory syncytial virus, and influenza virus (Hoenen et al., 2019). Since there are many functional similarities between SARS-CoV, SARS-CoV-2, and MERS-CoV, it is reasonable to screen drugs that were even moderately effective against SARS-CoV and MERS-CoV for SARS-CoV-2. These broad-spectrum anticoronavirus drugs could also be used against future emerging coronavirus infections. In particular, any such drugs that have an $\mathrm{IC}_{50}$ in the low nanomolar range (preferably less 
than $100 \mathrm{nM}$ ) with high efficacy in inhibiting viral infection in vitro would be most advantageous. Drug repurposing has been used in response to emerging infectious diseases to rapidly identify potential therapeutics. If FDA-approved drugs currently on the market for other diseases demonstrate antiSARS-CoV-2 activity, they could be repurposed for COVID-19 treatment. Several groups have identified compounds with anti-SARS-CoV-2 activity by repurposing select FDA-approved drugs (Choy et al., 2020; Jeon et al., 2020; Wang et al., 2020b). In addition, high-throughput drug repurposing screens have also been successfully used to identify such compounds (Table 1). The National Center for Advancing Translational Sciences also provides an online open science data portal for COVID-19 drug repurposing (https://ncats.nih.gov/expertise/ covid19-open-data-portal; K. R. Brimacombe et al., preprint, DOI: https://doi.org/10.1101/2020.06.04.135046).

For compound screening with large-scale libraries and molecular target-based assays, biosafety level (BSL)-2 laboratories are commonly used. These assays take longer to develop but are usually without risk of infectivity to humans and are capable of higher throughput than live SARS-CoV-2 virus assays requiring BSL-3 facilities. However, the efficacy of active compounds identified from such high-throughput screening needs to be confirmed with live SARS-CoV-2 virus assays done in the BSL-3 environment. For example, virus pseudoparticles that contain viral structural proteins without the viral genome can be used to assay viral entry mechanisms. Cell lines expressing viral replicons that contain portions of the viral genome with reporter genes but without viral structure genes can also be used to assay viral replication mechanisms. These nonviral assays used for viral entry or replication are not infectious and can be used in a BSL-2 facility for screening large compound collections. This strategy has been used to screen compounds for BSL-3/4 viruses such as EBOV (Tscherne et al., 2010; Kouznetsova et al., 2014), Lassa virus (Cubitt et al., 2020), SARS, and MERS-CoV (de Wilde et al., 2014; Dyall et al., 2014). Recently, Letko et al. (2020) showed chimeric S proteins containing RBD of SARS-CoV-2 can confer receptor specificity to the full S protein sequence. This approach of nonconventional pseudotyping method is cost effective and can provide a faster way to screen viral-host interactions.

Therapeutic targets for COVID-19 can be directed toward the SARS-CoV-2 virus and its proteins or the host cell targets. Prevention of virus-host associations can fall in either of the two categories. Drugs targeting viral proteins have a major advantage, as they could potentially have higher specificity against the virus while having minimal adverse effects on humans. However, drug resistance may develop rapidly after treatment, particularly in RNA viruses where mutations occur frequently. Conversely, therapeutics targeting host cells may slow the development of drug resistance, as mutations in host cells are relatively rare (Hoenen et al., 2019). Importantly, drugs targeting host cells have greater potential for adverse effects. Possible treatment options under investigation for the prevention and control of SARS-CoV-2 infections in both categories are discussed below.

\section{SARS-CoV-2 Viral Entry Inhibitors}

Antibodies. Neutralizing antibodies can be used to prevent viral cell surface receptor binding to block viral entry. After viral entry, the viral replication cycle concludes in the assembly and budding of new viral progeny at the host cell surface (Murin et al., 2019). These processes can be disrupted by neutralizing antibodies that bind to the viral glycoprotein to block viral egress (Murin et al., 2019). Thus, neutralizing antibodies can prevent viral entry as well as viral release, thereby blocking the infection of neighboring cells. In vitro neutralization assays followed by in vivo protection in an animal model was the standard workflow for choosing neutralizing antibodies against filoviruses such as EBOV, which emerged as an outbreak in 2014 in West Africa (Saphire et al., 2018). A glycoprotein-targeting cocktail of antibodies rather than a single antibody design against EBOV was shown to be superior and is currently being used in areas of outbreaks (Hoenen et al., 2019). Similarly, several anti-influenza monoclonal antibodies are currently in various stages of clinical development, and most are directed toward the viral hemagglutinin glycoprotein (Corti et al., 2017). For both EBOV and influenza, some broadly reactive antibodies lacking in vitro neutralizing activity have shown in vivo efficacy under prophylactic settings, and thus, there is not a precise correlation between in vitro activities and in vivo protection (Corti et al., 2017; Tian et al., 2020). Neutralizing antibodies designed against SARS-CoV and MERS-CoV could potentially be effective against SARS-CoV-2. Several monoclonal antibodies targeting S protein of SARS-CoV and MERS-CoV have shown promising results in neutralizing infection in both in vitro and rodent models (Shanmugaraj et al., 2020). Since the structures of SARS-CoV-2, SARS-CoV, and MERS-CoV S protein and monoclonal antibody interaction sites have been determined, neutralizing antibodies against S protein of SARS-CoV-2 promises to be a viable therapeutic option.

Convalescent plasma therapy using plasma from patients recovered from COVID-19 to treat severe cases of COVID-19

TABLE 1

High-throughput drug repurposing screens against SARS-CoV-2

\begin{tabular}{|c|c|c|c|c|}
\hline Cell line & Assay type & Strain of SARS-CoV-2 & Library screened & Reference \\
\hline Caco-2 & $\mathrm{CPE}$ & Unspecified & $\begin{array}{l}5632 \text { compounds, including } 3488 \text { compounds } \\
\text { that have undergone clinical investigations }{ }^{a}\end{array}$ & $\begin{array}{c}\text { B. Ellinger et al., preprint, DOI: } \\
\text { https://doi.org/10.21203/rs.3.rs- } \\
23951 / \mathrm{v} / \mathrm{v} 1\end{array}$ \\
\hline Vero E6 & $\begin{array}{l}\text { Primary screen: CPE } \\
\text { Follow-up: N protein } \\
\text { immuno-fluorescence }\end{array}$ & $\begin{array}{l}\text { HKU-001a in 1' screen } \\
\text { USA-WA1/2020 for } \\
\text { follow-up }\end{array}$ & LOPAC 1280 and ReFRAME library ${ }^{a}$ & $\begin{array}{c}\text { L. Riva et al., preprint, DOI: } \\
\text { https://doi.org/10.1101/2020.04.16. } \\
044016\end{array}$ \\
\hline Vero E6 & $\mathrm{CPE}$ & BavPat1 strain & $\begin{array}{l}\text { Prestwick Chemical Library } \\
\text { (1520 approved drugs) }\end{array}$ & $\begin{array}{l}\text { F. Touret et al., preprint, DOI: } \\
\text { https://doi.org/10.1101/2020.04. } \\
03.023846\end{array}$ \\
\hline
\end{tabular}

CPE, cytopathic effect.

${ }^{a}$ Proprietary library. 
has shown positive results. Convalescent plasma contains neutralizing antibodies specifically against the SARS-CoV-2 virus and confers passive immunity to the recipient, thereby improving clinical outcomes when used prophylactically and in infected patients (Casadevall and Pirofski, 2020). RBDspecific monoclonal antibodies derived from SARS-CoV-2infected individuals was shown to have neutralizing activities against both pseudoviruses bearing the $\mathrm{S}$ protein as well as live SARS-CoV-2 viruses (B. Ju et al., preprint, DOI: https:// doi.org/10.1101/2020.03.21.990770). Treatment with convalescent plasma was shown to be successful in a small cohort of patients (Duan et al., 2020; Shen et al., 2020). Clinical trials are currently underway to determine whether COVID-19 convalescent plasma or "hyperimmune plasma" might be an effective treatment therapy for COVID-19. The Takeda Pharmaceutical Company has announced investigation into a new plasma derived therapy named TAK-888 that involves removing plasma from COVID-19 survivors and extracting coronavirus-specific antibodies to stimulate a potent immune response against SARS-CoV-2 in infected patients (Barlow et al., 2020).

Proteins, Peptides, Small Molecule Compounds, and Drugs. Viral entry can also be blocked by proteins, peptides, or small molecule compounds that bind to the viral S protein, thereby preventing the interaction of virus and host membrane. Recombinant soluble ACE2, which lacks the membrane anchor and can circulate in small amounts in the blood, can act as a decoy to bind SARS-CoV-2 S proteins and thus prevent viral entry (C. Lei et al., preprint, DOI: https://doi.org/10.1101/ 2020.02.01.929976). Clinical grade human recombinant soluble ACE2 was shown to successfully inhibit SARS-CoV-2 infection in engineered human blood vessel organoids and human kidney organoids (Monteil et al., 2020). Studies also show that soluble human ACE2 can significantly decrease SARS-CoV-2 viral entry (Ou et al., 2020) and recombinant proteins designed against the RBD of S protein of SARS-CoV-2 can successfully block entry of virus into cells (Tai et al., 2020; G. Zhang et al., preprint, DOI: https://doi.org/10.1101/ 2020.03.19.999318). Another class of proteins that may be useful in blocking viral entry into cells are lectins, which bind specific carbohydrate structures but lack intrinsic enzymatic activity (Mitchell et al., 2017). Lectins may inhibit viral entry and subsequent replication by interacting with coronavirus S proteins that are heavily glycosylated (Mitchell et al., 2017). Griffithsin is a lectin protein isolated from marine red algae and has proven antiviral properties (Mori et al., 2005). Griffithsin can potently inhibit viral entry by binding to the $\mathrm{S}$ glycoprotein and prevent SARS-CoV infection both in vitro and in vivo with minimal cytotoxic effects (O'Keefe et al., 2010). Similarly, griffithsin was shown to inhibit MERS-CoV infectivity and production in vitro with no significant cytotoxicity (Millet et al., 2016). Another lectin protein known as Urtica dioica agglutinin (UDA) was shown to significantly decrease mortality rates in a mouse model of SARS-CoV infection and was able to impede viral entry and replication (Day et al., 2009; Kumaki et al., 2011). However, UDA requires higher concentrations than griffithsin to achieve similar inhibitions of viral infections (O'Keefe et al., 2010), and high doses of UDA have toxic effects in mice (Kumaki et al., 2011). Based on these in vitro as well as preclinical results, griffithsin may well prove to be an effective SARS-CoV-2 entry inhibitor.
Peptides can also be designed against the highly conserved heptad repeat region located in the $\mathrm{S} 2$ subunit of the S protein, which can interfere with viral and host cellular membrane fusion. A lipopeptide, EK1C4, exhibited highly potent inhibitory activity against SARS-CoV-2 S protein-mediated membrane fusion in vitro and in vivo (Xia et al., 2020). Small molecules that block the binding of S protein to ACE2 can also be investigated as therapeutics for COVID-19 treatment. For example, the cysteine-cysteine chemokine receptor 5 antagonist maraviroc, which was approved in 2007 for the treatment of HIV infections, blocks HIV from binding to its coreceptor cysteine-cysteine chemokine receptor 5. Thus, a specific ACE2 inhibitor may be developed that blocks the binding of SARS-CoV-2 S protein to ACE2.

Additionally, the inhibitors of host cell proteases such as TMPRSS2, furin, and cathepsin that prime viral structure proteins for membrane fusion may also prevent SARS-CoV-2 entry. Developing these types of inhibitors as therapeutics may present challenges due to differentially expressed proteases in different tissues. Therefore, developing a broadspectrum protease inhibitor against SARS-CoV-2 might be beneficial. For example, the TMPRSS2 inhibitor camostat mesylate can block the entry of SARS-CoV-2 into Calu-3 human lung epithelial cells (Hoffmann et al., 2020a), but a combination of camostat mesylate and cathepsin $\mathrm{B} / \mathrm{L}$ inhibitor E-64d is required to completely block viral entry into Caco-2 cells (Hoffmann et al., 2020a). Nafamostat is another example of a serine protease inhibitor that can inhibit SARS-CoV-2 entry and infection (Hoffmann et al., 2020b; Wang et al., 2020a). However, compared with camostat mesylate, nafamostat blocks viral entry and replication with significantly greater efficacy (Hoffmann et al., 2020b; J. H. Shrimp et al., preprint, DOI: https://doi.org/10.1101/ 2020.06.23.167544). Nafamostat, approved as a treatment of pancreatitis in Japan and Germany with no major adverse effects, may also have anti-inflammatory properties that could aid patients with COVID-19 (Hoffmann et al., 2020b); clinical trials will determine its suitability as a COVID-19 therapeutic (Table 2).

Viral entry may also be inhibited by umifenovir (also known as arbidol), which is approved for the treatment of influenza in Russia and China. Arbidol potently blocks SARS-CoV-2 entry into cells and inhibits postentry stages of infection (Wang et al., 2020b). The lower $\mathrm{EC}_{50}$ value of $4.11 \mu \mathrm{M}$ against SARS-CoV-2 compared with influenza viruses gives arbidol the potential to be a clinically effective therapeutic against SARS-CoV-2 (Wang et al., 2020b). One clinical trial is set to determine the effectiveness of arbidol for the treatment of COVID-19-induced pneumonia (Table 2) and several others as a combination therapy. In addition, chlorpromazine, an FDA-approved antipsychotic and clathrin-dependent endocytosis inhibitor, also has anti-SARS-CoV-2 activity in vitro (M. Plaze et al., preprint, DOI: https://doi.org/10.1101/ 2020.05.05.079608) and is currently under investigation as a potential therapeutic for COVID-19 (Table 2).

\section{Viral Replication Inhibitors}

Inhibitors of viral nucleic acid synthesis are the best represented class of antiviral drugs that suppress viral replication in host cells (Hoenen et al., 2019). The most successful 3CLpro inhibitor is lopinavir, a protease inhibitor used to treat HIV 
TABLE 2

Clinical therapies for COVID-19

\begin{tabular}{|c|c|c|c|c|c|}
\hline Compound/treatment & Target & Phase & $\begin{array}{l}\text { ClinicalTrials.gov } \\
\text { identifier }\end{array}$ & Approved for other clinical treatment & Status \\
\hline Camostat mesilate & $\begin{array}{l}\text { Serine proteases, e.g., } \\
\text { TMPRSS2 }\end{array}$ & Phase $1 / 2$ & NCT04321096 & Acute pancreatitis (Japan) & Ongoing \\
\hline Chlorpromazine & $\begin{array}{l}\text { Clathrin-mediated } \\
\text { endocytosis }\end{array}$ & $\begin{array}{c}\text { Phase } 1 / 2 \\
\text { Phase } 3\end{array}$ & $\begin{array}{l}\text { NCT04354805 } \\
\text { NCT04366739 }\end{array}$ & $\begin{array}{c}\text { Schizophrenia, manic depression, } \\
\text { nausea, anxiety }\end{array}$ & $\begin{array}{l}\text { Not yet recruiting } \\
\text { Not yet recruiting }\end{array}$ \\
\hline $\begin{array}{l}\text { Ciclesonide, an inhaled } \\
\text { corticosteroid }\end{array}$ & $\begin{array}{c}\text { Viral nonstructural } \\
\text { protein } 15 \text { encoding an } \\
\text { endonuclease and host } \\
\text { process }\end{array}$ & Phase 2 & NCT04330586 & $\begin{array}{l}\text { Asthma and allergic rhinitis } \\
\text { (Schaffner and Skoner, 2009) }\end{array}$ & Not yet recruiting \\
\hline $\begin{array}{l}\text { Favipiravir (Avigan) with } \\
\text { tocilizumab }\end{array}$ & $\begin{array}{l}\text { RdRp } \\
\text { IL-6 }\end{array}$ & $\begin{array}{l}\text { Not } \\
\text { applicable }\end{array}$ & NCT04310228 & Influenza (Japan) & Ongoing \\
\hline $\begin{array}{l}\text { Hydroxychloroquine and } \\
\text { chloroquine }\end{array}$ & $\begin{array}{l}\text { Antiviral properties } \\
\text { unclear }\end{array}$ & Various & Multiple & $\begin{array}{l}\text { Malaria, autoimmune diseases } \\
\text { (e.g., lupus, rheumatoid arthritis) }\end{array}$ & Varies \\
\hline $\begin{array}{l}\text { Interferon- } \alpha 1 b \text { nasal } \\
\text { drops }\end{array}$ & $\begin{array}{l}\text { Host immune response } \\
\text { to virus }\end{array}$ & Phase 3 & NCT04320238 & None & Ongoing \\
\hline Ivermectin & $\begin{array}{c}\text { Viral transport into host } \\
\text { nucleus }\end{array}$ & Varies & Multiple & Antiparasitic & Ongoing \\
\hline $\begin{array}{l}\text { Lopinavir + ritonavir } \\
\text { (Kaletra) }\end{array}$ & 3CLpro & Phase 4 & NCT04252885 & HIV & $\begin{array}{l}\text { Ongoing; preliminary } \\
\text { results show no benefit } \\
\text { beyond standard care } \\
\text { (Baden and Rubin, 2020) }\end{array}$ \\
\hline $\begin{array}{l}\text { Lopinavir-ritonavir }+ \\
\text { ribavirin and } \\
\text { interferon beta-1b }\end{array}$ & $\begin{array}{c}\text { 3CLpro, viral } \\
\text { polymerase, host } \\
\text { immune response to } \\
\text { virus }\end{array}$ & Phase 2 & NCT04276688 & HIV & $\begin{array}{l}\text { Completed; significant } \\
\text { improvement in } \\
\text { outcomes (Hung et al., } \\
\text { 2020) }\end{array}$ \\
\hline Nafamostat & Serine protease & Phase 1 & NCT04352400 & $\begin{array}{l}\text { Pancreatitis (Japan and } \\
\text { Germany) }\end{array}$ & Not yet recruiting \\
\hline Niclosamide & Viral and host processes & $\begin{array}{l}\text { Phase } 2 \\
\text { and } 3\end{array}$ & NCT04345419 & Anthelminthic drug & Not yet recruiting \\
\hline Nitazoxanide & Viral and host processes & Various & Multiple & Antiparasitic drug & Ongoing \\
\hline Remdesivir & $\operatorname{RdRp}$ & Phase 3 & $\begin{array}{l}\text { NCT04257656 } \\
\text { NCT04252664 } \\
\text { NCT04292899 } \\
\text { NCT04280705 }\end{array}$ & HIV & $\begin{array}{l}\text { Terminated } \\
\text { Terminated } \\
\text { Ongoing } \\
\text { Ongoing }\end{array}$ \\
\hline $\begin{array}{l}\text { Tocilizumab or } \\
\text { sarilumaub }\end{array}$ & $\begin{array}{l}\text { Human mAb that } \\
\text { inhibits the IL- } 6 \\
\text { pathway by binding and } \\
\text { blocking the IL-6 } \\
\text { receptor }\end{array}$ & Various & Multiple & $\begin{array}{c}\text { Multiple, including chimeric } \\
\text { antigen receptor T cell-induced } \\
\text { cytokine release syndrome, other } \\
\text { autoimmune conditions (Barlow } \\
\text { et al., 2020) }\end{array}$ & Ongoing \\
\hline Umifenovir (Arbidol) & $\begin{array}{l}\text { Viral membrane fusion } \\
\text { of influenza a and } b\end{array}$ & Phase 4 & NCT04260594 & Influenza (Russia and China) & Not yet recruiting \\
\hline
\end{tabular}

infections that is usually marketed as a ritonavir-boosted form (lopinavir-ritonavir) (Zumla et al., 2016). Preliminary in vitro studies with ritonavir on SARS-CoV-2 infection have not shown much promise (Choy et al., 2020). However, there are clinical trials underway to test the efficacy of this drug in humans (Table 2). Specifically repurposing any inhibitors designed against SARS-CoV or MERS-CoV 3CLpro for SARS-CoV-2 may prove challenging. Although there is a high degree of sequence conservation in the active sites of SARS-CoV and MERS-CoV 3CLpro enzymes, most SARS-CoV 3CLpro inhibitors are inactive against MERS-CoV, indicating other important structural differences (Needle et al., 2015).

RdRP is another target for SARS-CoV-2 drug development. The sequences encoding the structure of RdRP in SARS-CoV, MERS-CoV, and SARS-CoV2 were found to be remarkably similar (Morse et al., 2020). Several RdRP inhibitors originally developed for other viruses are in active clinical trials to treat COVID-19 infections (Table 2). Remdesivir, a prodrug of an adenosine analog, was originally developed for the treatment of EBOV and has broad-spectrum antiviral activities against RNA viruses. Remdesivir successfully improved outcomes when used prophylactically and therapeutically in animal models of MERS-CoV (de Wit et al., 2020) as well as SARS (Sheahan et al., 2017). Treatment with remdesivir during early infection also showed significant clinical benefits in nonhuman primates infected with SARS-CoV-2 (Williamson et al., 2020). In patients with COVID-19, clinical improvements without adverse effects were noted in patients treated with remdesivir on a compassionate-use basis (Grein et al., 2020). In a randomized, controlled trial known as the Adaptive COVID-19 Treatment Trial, patients with COVID-19 who received remdesivir had significantly shorter recovery and mortality rates with no serious adverse events (Beigel et al., 2020). Due to these preliminary reports, FDA recently granted remdesivir emergency use authorization for the treatment of severely ill COVID-19 patients.

Other RdRP inhibitors include favipiravir and ribavirin. Favipiravir, a prodrug guanosine analog, is approved for the treatment of influenza in Japan and China. Favipiravir is not reported to have significant adverse effects; however, it may increase the risk for teratogenicity and embryotoxicity (Furuta et al., 2017). Ribavirin, another guanosine analog prodrug, is used for the treatment of severe respiratory syncytial virus infection, hepatitis $\mathrm{C}$ viral infection, and viral hemorrhagic fevers (Zumla et al., 2016; Tu et al., 2020). However, when used as a treatment for SARS-CoV infection in both preclinical (Day et al., 2009) and clinical settings (Stockman et al., 2006), ribavirin did not improve outcomes 
but instead had adverse effects. In addition, of these three drugs, only remdesivir has shown potent inhibition of SARSCoV-2 infection in vitro (Choy et al., 2020; Wang et al., 2020a). Therefore, pursuing specific SARS-CoV-2 RdRP inhibitors is a valid approach for COVID-19 drug development, but the efficacy and toxicities of these drugs will need to be closely scrutinized in clinical trials.

Recently, ivermectin was shown to potently inhibit SARSCoV-2 in vitro with a single treatment (Caly et al., 2020). Ivermectin is an FDA-approved drug for the treatment of parasitic infections. However, its suitability as a COVID-19 treatment is currently being examined in several clinical trials, including one that will test asymptomatic patients (ClinicalTrials.gov identifier: NCT04407507).

Four additional enzymes specific to SARS-CoV-2-helicase (Nsp13), 3'-5' exonuclease (Nsp14), uridine-specific endoribonuclease (Nsp15), and RNA-cap methyltransferase (Nsp16)_ may be considered as key targets for drug discovery (Gordon et al., 2020). In single-stranded positive-sense RNA viruses such as SARS-CoV-2, RNA helicases are essential for viral genome transcription and protein translation. Thus, inhibitors of viral helicases are attractive as therapeutic agents. At least one molecule inhibitor of SARS-CoV helicase without cell toxicity has been previously identified (Cho et al., 2015). However, despite significant efforts being made toward their development, helicase inhibitors are currently not available for clinical use (Briguglio et al., 2011). The SARS-CoV-2 exonuclease (Nsp14) cleaves nucleotides at $3^{\prime}$ end of RNA strand and is required for RNA replication (Romano et al., 2020). Uridine-specific endoribonuclease (Nsp15, EndoU) is an endoribonuclease that hydrolyzes single-stranded as well as double-stranded RNA at uridine residues. EndoU is highly conserved in all coronaviruses, which suggests its functional importance (Hackbart et al., 2020). Although its precise role in viral pathogenesis is not well established, it likely plays a role in evading host recognition (Deng and Baker, 2018). A recent study confirmed that EndoU contributes to delayed type I interferon response by cleaving 5 '-polyuridines from negative-sense viral RNAs, which otherwise activate host immune sensors (Hackbart et al., 2020). There are currently no approved inhibitors for viral-specific $3{ }^{\prime}-5$ ' exonuclease or EndoU. In coronaviruses, RNA-cap methyltransferase (Nsp16) forms a complex with its cofactor $\mathrm{Nsp10}$ (a 2-O-methyltransferase) for the addition of a cap to the 5 '-end of viral RNA. This addition enables the virus to escape innate immune recognition in host cells as well as enhance viral RNA translation (Wang et al., 2015). Unfortunately, there are currently no effective inhibitors or approved drugs for these enzymes that may be used as targets for antiviral drug development.

\section{Host Cell and Viral Targets for Antiviral Drug Development}

Viral replication requires a number of cellular proteins and machinery. Inhibiting host cell protein function may effectively combat viral infection. These host targets include the host cell proteases TMPRSS2, furin, and cathepsin and ACE2 receptor discussed above. Additionally, the host cell autophagy pathway is used by some coronaviruses for viral replication and viral assembly. Since coronaviruses may hijack autophagy mechanisms for viral double membrane vesicle formation and replication, the inhibition of cellular autophagy may be a useful antiviral strategy (Abdoli et al., 2018; Yang and Shen, 2020). Although the drugs targeting host cell proteins are more likely to cause adverse effects, patients might tolerate a short 7-14-day treatment regimen. Other complicating factors for targeting host proteins is the redundancy of human cellular function pathways and variations in different cells or tissues, which may reduce correlations between in vitro and in vivo efficacy studies. This issue could be overcome by utilizing a drug combination therapy with different mechanisms of action such as that seen with the successful treatment of HIV; see the review by Maeda et al. (2019). Alternatively, a single drug with multiple activities against both viral targets and host viral replication machineries may be more effective in treating SARS-CoV-2 infection than drugs acting on one viral target. These drugs with polypharmacology against SARS-CoV-2 infection are discussed below.

Chloroquine (CQ) or hydroxychloroquine (HCQ) is a well known FDA-approved antimalarial drug that can inhibit viral infections via multiple mechanisms. The mechanism of inhibition likely involves the prevention of endocytosis or rapid elevation of the endosomal $\mathrm{pH}$ and abrogation of virusendosome fusion (Devaux et al., 2020). CQ/HCQ also has antiinflammatory properties, which has led to its clinical use in conditions such as rheumatoid arthritis, lupus, and sarcoidosis (Savarino et al., 2003). After the advent of SARS in 2003, Savarino et al. (2003) postulated that the antiviral as well as anti-inflammatory properties of $\mathrm{CQ} / \mathrm{HCQ}$ might be beneficial for SARS treatment. In addition, viruses may engage host autophagic processes to enhance replication (Yang and Shen, 2020). Since CQ is a known inhibitor of autophagic flux, it may be beneficial in inhibiting viral replication. CQ was shown to be highly effective in the control of SARS-CoV-2 infection in vitro (Wang et al., 2020a). It can also potentially interfere with the terminal glycosylation of ACE2 receptor expression, thereby preventing SARS-CoV-2 receptor binding and subsequent spread of infection (Barlow et al., 2020). Andreani et al. (2020) found that HCQ significantly suppresses virus replication, and a combination of $\mathrm{HCQ}$ and azithromycin exhibits synergistic effects. However, the FDA has warned that the use of $\mathrm{CQ} / \mathrm{HCQ}$, particularly when used in conjunction with azithromycin, can cause abnormal heart rhythms such as QT interval prolongation and ventricular tachycardia. As of June 15, 2020, FDA has revoked the emergency use authorization of these drugs for the treatment of COVID-19. Several clinical trials are underway to test the efficacy of $\mathrm{CQ} / \mathrm{HCQ}$ in different settings, although a few have been withdrawn. In addition, a drug repurposing screen performed in different cell lines indicates that viral entry in lung epithelial Calu-3 cells is $\mathrm{pH}$-independent (M. Dittmar et al., preprint, DOI: https://doi.org/10.1101/2020.06.19.161042). Therefore, CQ may not be effective as a treatment against SARS-CoV-2.

Emetine, approved for amoebiasis, has broad antiviral activity against Zika virus, EBOV, Dengue virus, human cytomegalovirus, and HIV in vitro and in vivo. Emetine may elicit cardiotoxic and myotoxic effects with high doses; however, its potency as an antiviral is significantly lower than doses that cause toxicity (Yang et al., 2018). Emetine can act on multiple mechanisms such as viral RdRp inhibition, host cell lysosomal function, and blocking viral protein synthesis 
via inhibition of host cell 40 S ribosomal protein S14 (Yang et al., 2018). A combination of $6.25 \mu \mathrm{M}$ remdesivir and $0.195 \mu \mathrm{M}$ emetine showed synergistic effects in vitro against SARS-CoV-2 infection, but some of the compounds currently undergoing clinical trials such as ribavirin and favipiravir did not show clear antiviral effects (Choy et al., 2020). This suggests that combination therapy may be a superior therapeutic option for the treatment of COVID-19 due to synergistic effects.

Niclosamide, an antiparasitic drug approved by FDA, has shown great potential for repurposing to treat a variety of viral infections including SARS-CoV and MERS-CoV by targeting both host and viral components (Xu et al., 2020a). Preliminary studies showed that niclosamide has potent antiviral activity against SARS-CoV-2 in vitro with an $\mathrm{IC}_{50}$ of $0.28 \mu \mathrm{M}$ (Jeon et al., 2020). In addition, niclosasmide exhibits very low toxicities in vitro and in vivo (Chen et al., 2018), making it an attractive candidate.

Nitazoxanide is another antiparasitic prodrug approved by FDA with antiviral properties and is reportedly well tolerated in patients. Although the mechanisms of viral inhibition are not well understood, it is thought to target host-regulated pathways and not viral machinery (Rossignol, 2016). In keeping with this, it was shown that nitazoxanide significantly inhibits EBOV in vitro by enhancing host antiviral responses (Jasenosky et al., 2019). An in vitro study determined that nitazoxanide can inhibit SARS-CoV-2 at low-micromolar concentrations with an $\mathrm{EC}_{50}$ value of $2.12 \mu \mathrm{M}$ (Wang et al., 2020a). Several trials are currently ongoing to determine its clinical efficacy as a treatment of patients with COVID-19 or as a postexposure prophylaxis therapy.

\section{Prophylactic Treatment of SARS-CoV-2 Infection}

SARS-CoV-2 infects humans mainly through inhalation of virally contaminated aerosol droplets from infected subjects. Thus, nasal sprays containing agents that can neutralize the virus or block viral entry into host cells are one approach to prevent SARS-CoV-2 infection. There are preliminary reports that an antihistamine nasal spray can inhibit SARS-CoV-2 infection in vitro (G. Ferrer and J. Westover, preprint, DOI: https://doi.org/10.21203/rs.3.rs-25854/v1). In rhesus monkeys, a nasal spray formulation of interferon- $\alpha 2 \mathrm{~b}$ was successful in decreasing the severity of SARS-CoV viral infection (Gao et al., 2005). Meng and colleagues also reported that a nasal drop formula of recombinant human interferon- $\alpha 1 \mathrm{~b}$ prevented SARS-CoV-2 infection in an open label clinical trial (Z. Meng et al., preprint, DOI: https://doi.org/10.1101/2020.04.11.20061473). Additionally, it might be possible to achieve high local drug concentrations for drugs with low systemic distribution and/or dose limiting toxicity when delivered systemically. Therefore, nasal administration of drugs merits further studies as a useful strategy in preventing or reducing SARS-CoV-2 infection. Phytochemicals from naturally occurring plants, particularly lectins and polyphenols, might also prove to be valuable candidates as prophylactic or therapeutic treatment against SARS-CoV-2 (recently reviewed in Mani et al. (2020)).

\section{Other Treatments in Clinical Trials for COVID-19}

Several drugs that target viral life cycles directly as well as host biology are currently being investigated for COVID-19 and are summarized in Table 2 and depicted in Figure 1.
As previously discussed, in patients with severe cases of COVID-19, excessive inflammatory responses and cytokine release likely contributes to the severity of disease stimulating lung and other systemic injuries. The early modulation of these responses may help reduce the risk of acute respiratory distress (Barlow et al., 2020). To this end, therapies such as inhibitory human monoclonal antibodies against cytokines such as interleukin-6 (IL-6) are also being considered to help diminish the severity of excessive physiologic response to SARS-CoV-2. The efficacy of glucocorticoids, such as methylprednisolone or dexamethasone, for the treatment of COVID-19 is yet to be determined. However, preliminary reports indicate that dexamethasone may be beneficial in critically ill patients with COVID-19 (P. Horby et al., preprint, DOI: https://doi.org/10.1101/2020.06.22.20137273). In addition, ciclesonide, an inhaled corticosteroid might also prove an effective therapy as it has low cytotoxicity and can potently suppress SARS-CoV-2 growth in vitro (Jeon et al., 2020; S. Matsuyama et al., preprint, DOI: https://doi.org/ 10.1101/2020.03.11.987016).

\section{Vaccines for SARS-CoV-2}

Treating COVID-19 with drugs or convalescent plasma does not confer immunity; hence, there remains an unmet need for immediate and long-term disease prevention in the form of a vaccine. According to the World Health Organization, there are over 100 SARS-CoV-2 vaccine candidates under preclinical development, including 1) DNA-based vaccines, which contain DNA encoding immunogen in plasmids; 2) inactivated whole virus vaccines, which are heat or chemically inactivated; 3 ) live-attenuated vaccines, which contain viable but weakened virus; 4) RNA-based vaccines, where an RNA encoding the immunogen is directly introduced into the host; 5) replicating and nonreplicating viral vector-based vaccines, where viral vectors are used to introduce DNA-encoding immunogenic into the host; 6) protein subunits, which contain portions of a pathogen; and 7) virus-like particle-based vaccines, which contain nonpathogenic virus-like nanoparticles similar in composition to the virus of interest (https:/www.who.int/ publications/m/item/draft-landscape-of-covid-19-candidatevaccines). Several vaccines from these categories are also under clinical investigation. The types of vaccines and their platforms used are summarized in Table 3. The advantages and disadvantages of using different platforms of vaccines vary and are reviewed elsewhere (Amanat and Krammer, 2020).

There are high expectations for these vaccines to be available for distribution within a year. Undoubtedly, an effective vaccine is the ultimate tool for COVID-19 disease prevention, but there are some important aspects to consider. SARS-CoV and MERS-CoV emerged almost 20 and 10 years ago, respectively. To this date, there are no approved vaccinations to prevent either of these diseases, although there are several candidates in the unlicensed preclinical stage. Effective vaccines are still not available for many infectious diseases such as malaria, HIV, EBOV, and Zika virus. Vaccine development typically takes 10-15 years and is associated with high costs (Zheng et al., 2018). In addition, rapid mutations arising in viral RNA could potentially render these vaccines ineffective. RNA viruses are known to mutate with high frequency, but thus far there do not seem to be many differences in the S protein amino acid residue sequences in emergent $\mathrm{SARS}-\mathrm{CoV}-2$ variants from 


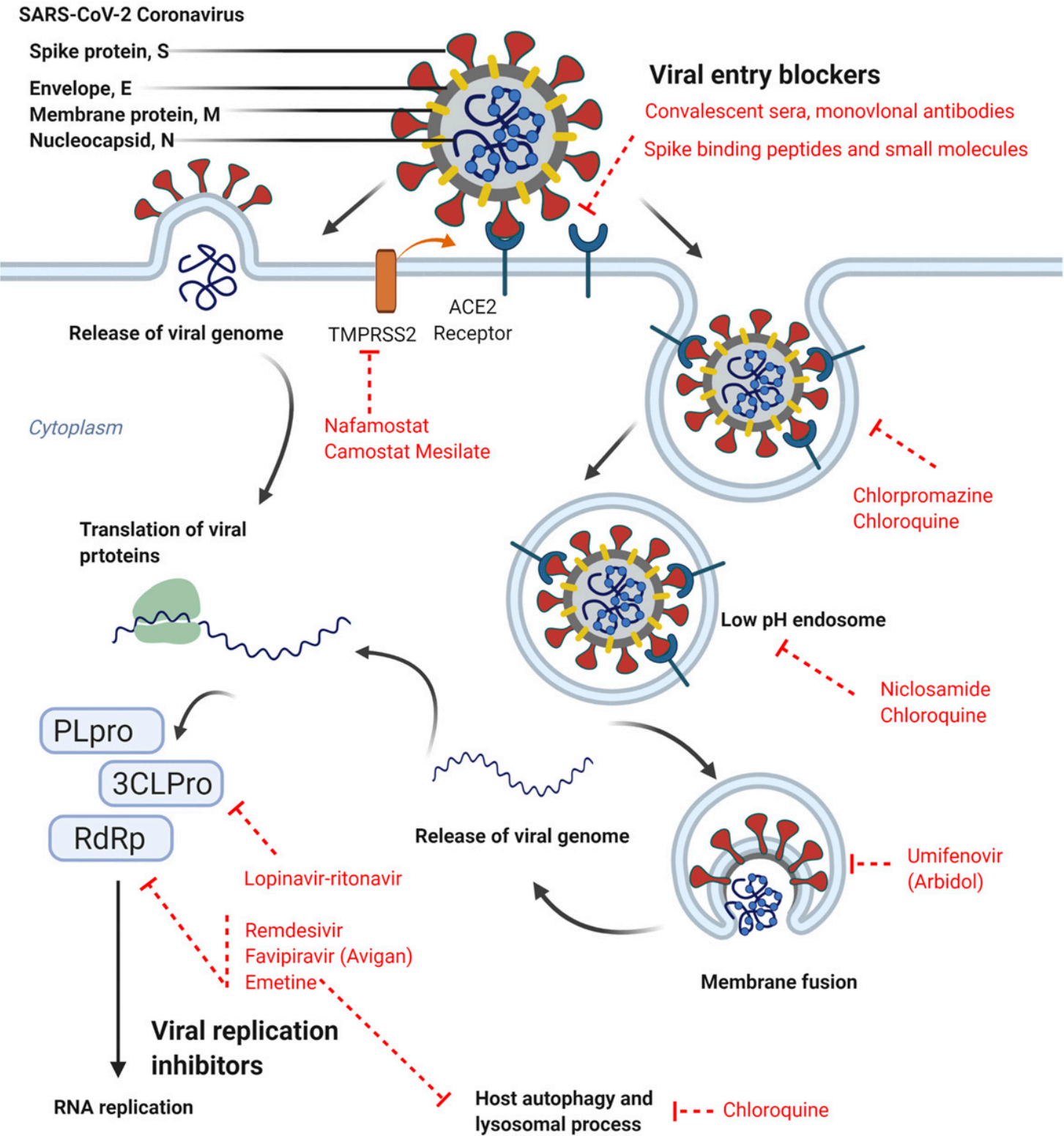

Fig. 1. SARS-CoV-2 spike (S) protein binds the cell surface receptor ACE2 on host cells. Viral genome is delivered into the host cytosol by 1 ) directly fusing with the plasma membrane after being cleaved and activated by the serine protease TMPRSS2 or 2) using the host cell's endocytic machinery in which the endocytosed virions are subjected to an activation step in the endosome. The viral genome also functions as the messenger RNA, which is translated into proteins, such as 3CLPro, papain-like cysteine protease (PLpro), and RdRp, by host cell machineries. The SARS-CoV-2 genome also encodes the structural proteins $(\mathrm{S})$, envelope $(\mathrm{E})$, membrane $(\mathrm{M})$, and nucleocapsid $(\mathrm{N})$. RdRP is essential for viral replication and therefore is an attractive target for anti-SARS-CoV-2 drugs. Drugs that are currently in clinical trials are shown here in red, along with their targets of viral life cycle or viral-host interactions. Figure created in BioRender.

different countries (Robson, 2020). Antibodies induced by vaccination could also potentially increase the risk and severity of disease in subsequent host-pathogen encounters (Kulkarni, 2020). The production of these antibodies may sometimes prove beneficial to the virus instead of the host by facilitating viral entry and replication in the target cell in a phenomenon known as antibody-dependent enhancement (ADE) of infection (Kulkarni, 2020). ADE has been noted in cases of dengue virus, HIV, respiratory syncytial virus, and influenza virus but has not been confirmed for SARS or EBOV (Kulkarni, 2020). However, preliminary results in animal models of SARS-CoV-2 infection are promising. In both rodents (K. S. Corbett et al., preprint,
DOI: https://doi.org/10.1101/2020.06.11.145920) and nonhuman primates (Gao et al., 2020), vaccinations against SARS-CoV-2 have shown protection without any observable ADE. In addition, positive outcomes have been noted in participants of small study in terms of tolerability and immunogenicity (Zhu et al., 2020).

\section{Perspectives and Conclusion}

Safe and effective viral therapeutics or vaccine development necessitates that data initially be obtained from preclinical in vitro or animal models. However, preclinically developed drug candidates often fail in human clinical trials 
TABLE 3

Potential vaccines in clinical trials for COVID-19 as of June 29, 2020

Sources: who.int/publications/m/item/draft-landscape-of-covid-19-candidate-vaccines; clinicaltrials.gov; clinicaltrialsregister.eu.

\begin{tabular}{|c|c|c|c|c|}
\hline Vaccine category & Vaccine type & Vaccine developer & Phase & Vaccine identifier \\
\hline \multirow[t]{2}{*}{ DNA based } & DNA plasmid + electroporation & Inovio Pharmaceuticals & Phase 1 & NCT04336410 \\
\hline & DNA vaccine, GX-19 & Genexine Consortium & Phase 1 & NCT04445389 \\
\hline \multirow[t]{5}{*}{ Inactivated virus } & Inactivated & Beijing Institute of Biologic Products & Phase $1 / 2$ & ChiCTR2000032459 \\
\hline & Inactivated & Wuhan Institute of Biologic Products & Phase 1/2 & ChiCTR2000031809 \\
\hline & Inactivated & Sinovac Research \& Development Co., Ltd & Phase $1 / 2$ & NCT04352608 \\
\hline & & & Phase $1 / 2$ & NCT04383574 \\
\hline & Inactivated & Chinese Academy of Medical Sciences & Phase $1 / 2$ & NCT04412538 \\
\hline \multirow[t]{11}{*}{$\begin{array}{l}\text { Nonreplicating } \\
\text { viral vector }\end{array}$} & Adenovirus type 5 & $\begin{array}{c}\text { CanSino Biologic Inc; preliminary results } \\
\text { (Zhu et al., 2020) }\end{array}$ & Phase 1 & NCT04313127 \\
\hline & & Beijing Institute of Biotechnology & Phase 2 & ChiCTR2000031781 \\
\hline & ChAdOx1-S & University of Oxford/AstraZeneca & $\begin{array}{c}\text { Phase } 3 \\
\text { Phase } 2 / 3\end{array}$ & ISRCTN89951424 \\
\hline & & & Phase $2 / 3$ & 2020-001228-32 \\
\hline & & & Phase $1 / 2$ & NCT04400838 \\
\hline & & & Phase $1 / 2$ & $2020-001072-15$ \\
\hline & & & & NCT04324606 \\
\hline & Adenoviral & Gamaleya Research Institute & Phase 1 & NCT04436471 \\
\hline & & & Phase $1 / 2$ & NCT04437875 \\
\hline & Adeno based & Chinese Academy of Medical Sciences & Phase 2 & NCT04341389 \\
\hline & & & & NCT04412538 \\
\hline \multirow[t]{3}{*}{ Protein subunit } & $\begin{array}{c}\text { Recombinant SARS-CoV-2 trimeric S } \\
\text { protein subunit }\end{array}$ & Clover Biopharmaceuticals Inc./GSK/Dynavax & Phase 1 & NCT04405908 \\
\hline & Recombinant protein (RBD dimer) & $\begin{array}{c}\text { Anhui Zhifei Longcom Biologic Pharmacy Co., } \\
\text { Ltd/The Second Affiliated Hospital of } \\
\text { Chongqing Medical University/Beijing Chao } \\
\text { Yang Hospital }\end{array}$ & Phase 1 & NCT04445194 \\
\hline & $\begin{array}{l}\text { Full length recombinant SARS CoV-2 } \\
\text { glycoproteinnanoparticle vaccine } \\
\text { adjuvanted with Matrix M }\end{array}$ & Novavax & Phase $1 / 2$ & NCT04368988 \\
\hline \multirow[t]{7}{*}{ RNA } & Messenger RNA in lipid nanoparticle & Moderna/NIH/NIAID; related preclinical study & Phase 1 & NCT04283461 \\
\hline & & (Corbett et al., 2020) & Phase 2 & NCT04405076 \\
\hline & Messenger RNA in lipid nanoparticle & BioNTech/Fosun Pharma/Pfizer & Phase $1 / 2$ & $2020-001038-36$ \\
\hline & & & Phase 1 & NCT04368728 \\
\hline & mRNA & Curevac & Phase 1 & NCT04449276 \\
\hline & mRNA & $\begin{array}{l}\text { People's Liberation Army (PLA) Academy of } \\
\text { Military Sciences/Walvax Biotech }\end{array}$ & Phase 1 & ChiCTR2000034112 \\
\hline & $\begin{array}{c}\text { Self-amplifying RNA in lipid } \\
\text { nanoparticle }\end{array}$ & Imperial College London & Phase 1 & ISRCTN17072692 \\
\hline
\end{tabular}

GSK, GlaxoSmithKline; NIAID, National Institute of Allergy and Infectious Diseases; NIH, National Institutes of Health.

(Seyhan, 2019). For example, remdesivir efficiently suppressed EBOV replication in vitro with nanomolar activity and also protected $100 \%$ of infected animals from mortality (Warren et al., 2016). However, these results were not recapitulated in humans for the treatment of EBOV infections, and the remdesivir treatment group was terminated due to low efficacy and increased toxicities (Mulangu et al., 2019). In general, viral infections are highly dependent on host cells. Therefore, successful clinical translation of SARS-CoV-2 drugs would require careful considerations of the testing platform. These might include suitable cell models for in vitro viral infection assays as well as human induced pluripotent stem cell-derived airway and gut organoids.

SARS-CoV infection was curtailed by rigorous isolation, but MERS-CoV infection is still a concern, albeit at lower infectious rate than SARS-CoV-2. SARS-CoV-2 infections present a clinical challenge as they are highly transmissible in part due to asymptomatic transmission. Therefore, the approach taken with SARS-CoV would certainly help curtail the spread of SARS-CoV-2, but with the current spread of disease, such large-scale isolation and quarantine efforts have proven difficult. Therefore, better therapeutic options are essential. Multitarget treatment approaches of drug combination therapy have been successful with HIV treatment and will likely be a viable therapeutic strategy for the treatment of COVID-19. Combination drug therapy has been extensively used for the treatment of HIV, cancer, and severe bacterial and fungal infections. Recently, patients with COVID-19 treated with the triple antiviral drug cocktail lopinavir-ritonavir-ribavirin with interferon beta-1b compared with lopinavir-ritonavir alone showed significant improvements in clinical outcomes (Hung et al., 2020). In addition, the combination drugs elicited no further side effects compared with the two-drug controls. Combination drug therapy may increase toxicity compared with single drug treatment. A meta-analysis of published trials evaluated the efficacy and toxicity of two-drug full dose combination therapy versus a single full dose drug for the treatment of rheumatoid arthritis (Felson et al., 1994). The study concluded that combination therapy led to a $9 \%$ patient withdrawal rate due to significant increases in adverse effects. Therefore, with combination therapy approaches, drugs with dose limiting toxicity as monotherapies can be used with lower individual drug doses, thereby reducing toxicity and synergistically enhancing therapeutic efficacy (Sun et al., 2016; Hoenen et al., 2019). As an example, several FDA-approved drugs found in a drug repurposing screen showed activity against EBOV but were not clinically useful, as their plasma concentrations were not high enough to inhibit infection in humans (Kouznetsova et al., 2014). However, drug combination therapy 
using three of these drugs at low concentrations was able to effectively block EBOV infection in vitro (Sun et al., 2017). Thus, synergistic drug combinations can be particularly useful for drug repurposing (Zheng et al., 2018). For COVID-19, drug combination therapies with multiple agents that have different mechanisms of action, including inhibition of viral entry and replication, as well as inhibition of host immune responses, would be a practical and useful approach for disease intervention.

\section{Authorship Contributions}

Wrote or contributed to the writing of the manuscript: Shyr, Gorshkov, Chen, Zheng.

\section{References}

Abdoli A, Alirezaei M, Mehrbod P, and Forouzanfar F (2018) Autophagy: the multipurpose bridge in viral infections and host cells. Rev Med Virol 28:e1973.

Amanat F and Krammer F (2020) SARS-CoV-2 vaccines: status report. Immunity 52 583-589.

Andreani J, Le Bideau M, Duflot I, Jardot P, Rolland C, Boxberger M, Wurtz N, Rolain JM, Colson P, La Scola B, et al. (2020) In vitro testing of combined hydroxychloroquine and azithromycin on SARS-CoV-2 shows synergistic effect. Microb Pathog 145:104228.

Baden LR and Rubin EJ (2020) Covid-19 - the search for effective therapy. N Engl J Med 382:1851-1852.

Barlow A, Landolf KM, Barlow B, Yeung SYA, Heavner JJ, Claassen CW, and Heavner MS (2020) Review of emerging pharmacotherapy for the treatment of coronavirus disease 2019. Pharmacotherapy 40:416-437.

Beigel JH, Tomashek KM, Dodd LE, Mehta AK, Zingman BS, Kalil AC, Hohmann E, Chu HY, Luetkemeyer A, Kline S, et al. ACTT-1 Study Group Members (2020) Remdesivir for the treatment of covid-19 - preliminary report. $N$ Engl J Med DOI: 10.1056/NEJMoa2007764 [published ahead of print].

Briguglio I, Piras S, Corona P, and Carta A (2011) Inhibition of RNA helicases of ssRNA(+) virus belonging to Flaviviridae, Coronaviridae and Picornaviridae families. Int J Med Chem 2011:213135.

Caly L, Druce JD, Catton MG, Jans DA, and Wagstaff KM (2020) The FDA-approved drug ivermectin inhibits the replication of SARS-CoV-2 in vitro. Antiviral Res 178 104787.

Casadevall A and Pirofski LA (2020) The convalescent sera option for containing COVID-19. J Clin Invest 130:1545-1548.

Chen W, Mook RA Jr., Premont RT, and Wang J (2018) Niclosamide: beyond an antihelminthic drug. Cell Signal 41:89-96.

Cho JB, Lee JM, Ahn HC, and Jeong YJ (2015) Identification of a novel small molecule inhibitor against SARS coronavirus helicase. J Microbiol Biotechnol 25:2007-2010.

Choy KT, Wong AY, Kaewpreedee P, Sia SF, Chen D, Hui KPY, Chu DKW, Chan MCW, Cheung PP, Huang X, et al. (2020) Remdesivir, lopinavir, emetine, and homoharringtonine inhibit SARS-CoV-2 replication in vitro. Antiviral Res 178: 104786.

Corti D, Cameroni E, Guarino B, Kallewaard NL, Zhu Q, and Lanzavecchia A (2017) Tackling influenza with broadly neutralizing antibodies. Curr Opin Virol 24:60-69.

Cubitt B, Ortiz-Riano E, Cheng BY, Kim YJ, Yeh CD, Chen CZ, Southall NOE, Zheng W, Martinez-Sobrido L, and de la Torre JC (2020) A cell-based, infectiousfree, platform to identify inhibitors of lassa virus ribonucleoprotein (vRNP) activity. Antiviral Res 173:104667.

Day CW, Baric R, Cai SX, Frieman M, Kumaki Y, Morrey JD, Smee DF, and Barnard DL (2009) A new mouse-adapted strain of SARS-CoV as a lethal model for evaluating antiviral agents in vitro and in vivo. Virology 395:210-222.

Deng X and Baker SC (2018) An "Old" protein with a new story: coronavirus endoribonuclease is important for evading host antiviral defenses. Virology 517:157-163.

Devaux CA, Rolain JM, Colson P, and Raoult D (2020) New insights on the antiviral effects of chloroquine against coronavirus: what to expect for COVID-19? Int $J$ Antimicrob Agents 55:105938.

de Wilde AH, Jochmans D, Posthuma CC, Zevenhoven-Dobbe JC, van Nieuwkoop S, Bestebroer TM, van den Hoogen BG, Neyts J, and Snijder EJ (2014) Screening of an FDA-approved compound library identifies four small-molecule inhibitors of Middle East respiratory syndrome coronavirus replication in cell culture. Antimicrob Agents Chemother 58:4875-4884.

de Wit E, Feldmann F, Cronin J, Jordan R, Okumura A, Thomas T, Scott D, Cihlar T, and Feldmann H (2020) Prophylactic and therapeutic remdesivir (GS-5734) treatment in the rhesus macaque model of MERS-CoV infection. Proc Natl Acad Sci USA 117:6771-6776.

Drosten C, Günther S, Preiser W, van der Werf S, Brodt HR, Becker S, Rabenau H, Panning M, Kolesnikova L, Fouchier RA, et al. (2003) Identification of a novel coronavirus in patients with severe acute respiratory syndrome. $N$ Engl J Med 348: 1967-1976.

Duan K, Liu B, Li C, Zhang H, Yu T, Qu J, Zhou M, Chen L, Meng S, Hu Y, et al. (2020) Effectiveness of convalescent plasma therapy in severe COVID-19 patients. Proc Natl Acad Sci USA 117:9490-9496.

Dyall J, Coleman CM, Hart BJ, Venkataraman T, Holbrook MR, Kindrachuk J, Johnson RF, Olinger GG Jr., Jahrling PB, Laidlaw M, et al. (2014) Repurposing of clinically developed drugs for treatment of Middle East respiratory syndrome coronavirus infection. Antimicrob Agents Chemother 58:4885-4893.

Felson DT, Anderson JJ, and Meenan RF (1994) The efficacy and toxicity of combination therapy in rheumatoid arthritis. A meta-analysis. Arthritis Rheum 37: 1487-1491.
Furuta Y, Komeno T, and Nakamura T (2017) Favipiravir (T-705), a broad spectrum inhibitor of viral RNA polymerase. Proc Jpn Acad, Ser B, Phys Biol Sci 93: $449-463$

Gao H, Zhang LL, Wei Q, Duan ZJ, Tu XM, Yu ZA, Deng W, Zhang LP, Bao LL, Zhang $\mathrm{B}$, et al. (2005) [Preventive and therapeutic effects of recombinant IFN-alpha2b nasal spray on SARS-CoV infection in Macaca mulata]. Zhonghua Shi Yan He Lin Chuang Bing Du Xue Za Zhi 19:207-210.

Gao Q, Bao L, Mao H, Wang L, Xu K, Yang M, Li Y, Zhu L, Wang N, Lv Z, et al. (2020) Development of an inactivated vaccine candidate for SARS-CoV-2. Science 369: $77-81$.

Gierer S, Bertram S, Kaup F, Wrensch F, Heurich A, Krämer-Kühl A, Welsch K, Winkler M, Meyer B, Drosten C, et al. (2013) The spike protein of the emerging betacoronavirus EMC uses a novel coronavirus receptor for entry, can be activated by TMPRSS2, and is targeted by neutralizing antibodies. $J$ Virol 87:5502-5511.

Glowacka I, Bertram S, Müller MA, Allen P, Soilleux E, Pfefferle S, Steffen I, Tsegaye TS, He Y, Gnirss K, et al. (2011) Evidence that TMPRSS2 activates the severe acute respiratory syndrome coronavirus spike protein for membrane fusion and reduces viral control by the humoral immune response. J Virol 85:4122-4134

Grein J, Ohmagari N, Shin D, Diaz G, Asperges E, Castagna A, Feldt T, Green G, Green ML, Lescure FX, et al. (2020) Compassionate use of remdesivir for patients with severe covid-19. N Engl J Med 382:2327-2336.

Hackbart M, Deng X, and Baker SC (2020) Coronavirus endoribonuclease targets viral polyuridine sequences to evade activating host sensors. Proc Natl Acad Sci USA 117: 8094-8103.

Hoenen T, Groseth A, and Feldmann H (2019) Therapeutic strategies to target the Ebola virus life cycle. Nat Rev Microbiol 17:593-606.

Hoffmann M, Kleine-Weber H, Schroeder S, Krüger N, Herrler T, Erichsen S, Schiergens TS, Herrler G, Wu NH, Nitsche A, et al. (2020a) SARS-CoV-2 cell entry depends on ACE2 and TMPRSS2 and is blocked by a clinically proven protease inhibitor. Cell 181:271-280.e8.

Hoffmann M, Schroeder S, Kleine-Weber H, Müller MA, Drosten C, and Pöhlmann S (2020b) Nafamostat mesylate blocks activation of SARS-CoV-2: new treatment option for COVID-19. Antimicrob Agents Chemother 64:e00754-20.

Hung IF, Lung KC, Tso EY, Liu R, Chung TW, Chu MY, Ng YY, Lo J, Chan J, Tam AR et al. (2020) Triple combination of interferon beta-1b, lopinavir-ritonavir, and ribavirin in the treatment of patients admitted to hospital with COVID-19: an open-label, randomised, phase 2 trial. Lancet 395:1695-1704.

Iwata-Yoshikawa N, Okamura T, Shimizu Y, Hasegawa H, Takeda M, and Nagata N (2019) TMPRSS2 contributes to virus spread and immunopathology in the airways of murine models after coronavirus infection. $J$ Virol 93:e01815-18.

Jasenosky LD, Cadena C, Mire CE, Borisevich V, Haridas V, Ranjbar S, Nambu A, Bavari S, Soloveva V, Sadukhan S, et al. (2019) The FDA-approved oral drug nitazoxanide amplifies host antiviral responses and inhibits Ebola virus. iScience 19 $1279-1290$

Jeon S, Ko M, Lee J, Choi I, Byun SY, Park S, Shum D, and Kim S (2020) Identification of antiviral drug candidates against SARS-CoV-2 from FDA-approved drugs. Antimicrob Agents Chemother 64:e00819-20.

Kouznetsova J, Sun W, Martínez-Romero C, Tawa G, Shinn P, Chen CZ, Schimmer A Sanderson P, McKew JC, Zheng W, et al. (2014) Identification of 53 compounds that block Ebola virus-like particle entry via a repurposing screen of approved drugs. Emerg Microbes Infect 3:e84.

Kuba K, Imai Y, Rao S, Gao H, Guo F, Guan B, Huan Y, Yang P, Zhang Y, Deng W, et al. (2005) A crucial role of angiotensin converting enzyme 2 (ACE2) in SARS coronavirus-induced lung injury. Nat Med 11:875-879.

Kulkarni R (2020) Antibody-dependent enhancement of viral infections, in Dynamics of Immune Activation in Viral Diseases (Bramhachari PV ed) pp 9-41, Springer, Singapore.

Kumaki Y, Wandersee MK, Smith AJ, Zhou Y, Simmons G, Nelson NM, Bailey KW, Vest ZG, Li JK, Chan PK, et al. (2011) Inhibition of severe acute respiratory syndrome coronavirus replication in a lethal SARS-CoV BALB/c mouse model by stinging nettle lectin, Urtica dioica agglutinin. Antiviral Res 90:22-32.

Letko M, Marzi A, and Munster V (2020) Functional assessment of cell entry and receptor usage for SARS-CoV-2 and other lineage B betacoronaviruses. Nat Microbiol 5:562-569.

Li X, Geng M, Peng Y, Meng L, and Lu S (2020) Molecular immune pathogenesis and diagnosis of COVID-19. J Pharm Anal 10:102-108.

Lu R, Zhao X, Li J, Niu P, Yang B, Wu H, Wang W, Song H, Huang B, Zhu N, et al (2020) Genomic characterisation and epidemiology of 2019 novel coronavirus: implications for virus origins and receptor binding. Lancet 395:565-574.

Maeda K, Das D, Kobayakawa T, Tamamura H, and Takeuchi H (2019) Discovery and development of anti-HIV therapeutic agents: progress towards improved HIV medication. Curr Top Med Chem 19:1621-1649.

Mani JS, Johnson JB, Steel JC, Broszczak DA, Neilsen PM, Walsh KB, and Naiker M (2020) Natural product-derived phytochemicals as potential agents against coronaviruses: a review. Virus Res 284:197989.

Mathewson AC, Bishop A, Yao Y, Kemp F, Ren J, Chen H, Xu X, Berkhout B, van der Hoek L, and Jones IM (2008) Interaction of severe acute respiratory syndromecoronavirus and NL63 coronavirus spike proteins with angiotensin converting enzyme-2. J Gen Virol 89:2741-2745.

Matsuyama S, Nagata N, Shirato K, Kawase M, Takeda M, and Taguchi F (2010) Efficient activation of the severe acute respiratory syndrome coronavirus spike protein by the transmembrane protease TMPRSS2. J Virol 84:12658-12664.

Matsuyama S, Nao N, Shirato K, Kawase M, Saito S, Takayama I, Nagata N, Sekizuka T, Katoh H, Kato F, et al. (2020) Enhanced isolation of SARS-CoV-2 by TMPRSS2-expressing cells. Proc Natl Acad Sci USA 117:7001-7003.

Millet JK, Séron K, Labitt RN, Danneels A, Palmer KE, Whittaker GR, Dubuisson J, and Belouzard S (2016) Middle East respiratory syndrome coronavirus infection is inhibited by griffithsin. Antiviral Res 133:1-8.

Mitchell CA, Ramessar K, and O'Keefe BR (2017) Antiviral lectins: selective inhibitors of viral entry. Antiviral Res 142:37-54. 
Monteil V, Kwon H, Prado P, Hagelkruys A, Wimmer RA, Stahl M, Leopoldi A, Garreta E, Hurtado Del Pozo C, Prosper F, et al. (2020) Inhibition of SARS-CoV-2 infections in engineered human tissues using clinical-grade soluble human ACE2. Cell 181:905-913.e7.

Mori T, O'Keefe BR, Sowder RC II, Bringans S, Gardella R, Berg S, Cochran P, Turpin JA, Buckheit RW Jr., McMahon JB, et al. (2005) Isolation and characterization of griffithsin, a novel HIV-inactivating protein, from the red alga Griffithsia sp. $J$ Biol Chem 280:9345-9353.

Morse JS, Lalonde T, Xu S, and Liu WR (2020) Learning from the past: possible urgent prevention and treatment options for severe acute respiratory infections caused by 2019-nCoV. ChemBioChem 21:730-738.

Mulangu S, Dodd LE, Davey RT Jr., Tshiani Mbaya O, Proschan M, Mukadi D, Lusakibanza Manzo M, Nzolo D, Tshomba Oloma A, Ibanda A, et al. PALM Writing Group PALM Consortium Study Team (2019) A randomized, controlled trial of Ebola virus disease therapeutics. $N$ Engl $J$ Med 381:2293-2303.

Murin CD, Wilson IA, and Ward AB (2019) Antibody responses to viral infections: a structural perspective across three different enveloped viruses. Nat Microbiol 4: 734-747.

Needle D, Lountos GT, and Waugh DS (2015) Structures of the Middle East respiratory syndrome coronavirus 3C-like protease reveal insights into substrate specificity. Acta Crystallogr D Biol Crystallogr 71:1102-1111.

O'Keefe BR, Giomarelli B, Barnard DL, Shenoy SR, Chan PKS, McMahon JB, Palmer KE, Barnett BW, Meyerholz DK, Wohlford-Lenane CL, et al. (2010) Broad-spectrum in vitro activity and in vivo efficacy of the antiviral protein griffithsin against emerging viruses of the family Coronaviridae. $J$ Virol 84:2511-2521.

Ou X, Liu Y, Lei X, Li P, Mi D, Ren L, Guo L, Guo R, Chen T, Hu J, et al. (2020) Characterization of spike glycoprotein of SARS-CoV-2 on virus entry and its immune cross-reactivity with SARS-CoV. Nat Commun 11:1620.

Puelles VG, Lutgehetmann M, Lindenmeyer MT, Sperhake JP, Wong MN, Allweiss L, Chilla S, Heinemann A, Wanner N, Liu S, et al. (2020) Multiorgan and renal tropism of SARS-CoV-2. N Engl J Med DOI: 10.1056/NEJMc2011400 [published ahead of print].

Qing E and Gallagher T (2020) SARS coronavirus redux. Trends Immunol 41:271-273

Robson B (2020) Computers and viral diseases. Preliminary bioinformatics studies on the design of a synthetic vaccine and a preventative peptidomimetic antagonist against the SARS-CoV-2 (2019-nCoV, COVID-19) coronavirus. Comput Biol Med 119: 103670 .

Romano M, Ruggiero A, Squeglia F, Maga G, and Berisio R (2020) A structural view of SARS-CoV-2 RNA replication machinery: RNA synthesis, proofreading and final capping. Cells 9:1267.

Rossignol JF (2016) Nitazoxanide, a new drug candidate for the treatment of Middle East respiratory syndrome coronavirus. J Infect Public Health 9:227-230.

Saphire EO, Schendel SL, Gunn BM, Milligan JC, and Alter G (2018) Antibodymediated protection against Ebola virus. Nat Immunol 19:1169-1178.

Savarino A, Boelaert JR, Cassone A, Majori G, and Cauda R (2003) Effects of chloroquine on viral infections: an old drug against today's diseases? Lancet Infect Dis $\mathbf{3}$ $722-727$

Schaffner TJ and Skoner DP (2009) Ciclesonide: a safe and effective inhaled corticosteroid for the treatment of asthma. J Asthma Allergy 2:25-32.

Seyhan AA (2019) Lost in translation: the valley of death across preclinical and clinical divide - identification of problems and overcoming obstacles. Transl Med Commun 4:18.

Shanmugaraj B, Siriwattananon K, Wangkanont K, and Phoolcharoen W (2020) Perspectives on monoclonal antibody therapy as potential therapeutic intervention for Coronavirus disease-19 (COVID-19). Asian Pac J Allergy Immunol 38:10-18.

Sheahan TP, Sims AC, Graham RL, Menachery VD, Gralinski LE, Case JB, Leist SR, Pyrc K, Feng JY, Trantcheva I, et al. (2017) Broad-spectrum antiviral GS-5734 inhibits both epidemic and zoonotic coronaviruses. Sci Transl Med 9:eaal3653.

Shen C, Wang Z, Zhao F, Yang Y, Li J, Yuan J, Wang F, Li D, Yang M, Xing L, et al (2020) Treatment of 5 critically ill patients with COVID-19 with convalescent plasma. JAMA 323:1582-1589.

Shulla A, Heald-Sargent T, Subramanya G, Zhao J, Perlman S, and Gallagher T (2011) A transmembrane serine protease is linked to the severe acute respiratory syndrome coronavirus receptor and activates virus entry. $J$ Virol 85:873-882.

Sigrist CJ, Bridge A, and Le Mercier P (2020) A potential role for integrins in host cell entry by SARS-CoV-2. Antiviral Res 177:104759.

Stockman LJ, Bellamy R, and Garner P (2006) SARS: systematic review of treatment effects. PLoS Med 3:e343.

Sun W, He S, Martínez-Romero C, Kouznetsova J, Tawa G, Xu M, Shinn P, Fisher E, Long Y, Motabar O, et al. (2017) Synergistic drug combination effectively blocks Ebola virus infection. Antiviral Res 137:165-172.

Sun W, Sanderson PE, and Zheng W (2016) Drug combination therapy increases successful drug repositioning. Drug Discov Today 21:1189-1195.

Tai W, He L, Zhang X, Pu J, Voronin D, Jiang S, Zhou Y, and Du L (2020) Characterization of the receptor-binding domain (RBD) of 2019 novel coronavirus: implication for development of RBD protein as a viral attachment inhibitor and vaccine. Cell Mol Immunol 17:613-620.
Tang T, Bidon M, Jaimes JA, Whittaker GR, and Daniel S (2020) Coronavirus membrane fusion mechanism offers a potential target for antiviral development. Antiviral Res 178:104792.

Tian X, Li C, Huang A, Xia S, Lu S, Shi Z, Lu L, Jiang S, Yang Z, Wu Y, et al. (2020) Potent binding of 2019 novel coronavirus spike protein by a SARS coronavirusspecific human monoclonal antibody. Emerg Microbes Infect 9:382-385.

Tscherne DM, Manicassamy B, and García-Sastre A (2010) An enzymatic virus-like particle assay for sensitive detection of virus entry. J Virol Methods 163:336-343.

Tu YF, Chien CS, Yarmishyn AA, Lin YY, Luo YH, Lin YT, Lai WY, Yang DM, Chou SJ, Yang YP, et al. (2020) A review of SARS-CoV-2 and the ongoing clinical trials. Int J Mol Sci 21:2657.

Walls AC, Park YJ, Tortorici MA, Wall A, McGuire AT, and Veesler D (2020) Structure, function, and antigenicity of the SARS-CoV-2 spike glycoprotein. Cell 181: 281-292.e6.

Wan Y, Shang J, Graham R, Baric RS, and Li F (2020) Receptor recognition by the novel coronavirus from Wuhan: an analysis based on decade-long structural studies of SARS coronavirus. $J$ Virol 94:e00127-20.

Wang H, Yang P, Liu K, Guo F, Zhang Y, Zhang G, and Jiang C (2008) SARS coronavirus entry into host cells through a novel clathrin- and caveolae-independent endocytic pathway. Cell Res 18:290-301.

Wang M, Cao R, Zhang L, Yang X, Liu J, Xu M, Shi Z, Hu Z, Zhong W, and Xiao G (2020a) Remdesivir and chloroquine effectively inhibit the recently emerged novel coronavirus (2019-nCoV) in vitro. Cell Res 30:269-271.

Wang X, Cao R, Zhang H, Liu J, Xu M, Hu H, Li Y, Zhao L, Li W, Sun X, et al. (2020b) The anti-influenza virus drug, arbidol is an efficient inhibitor of SARS-CoV-2 in vitro. Cell Discov 6:28

Wang Y, Sun Y, Wu A, Xu S, Pan R, Zeng C, Jin X, Ge X, Shi Z, Ahola T, et al. (2015) Coronavirus nsp10/nsp16 methyltransferase can be targeted by nsp10-derived peptide in vitro and in vivo to reduce replication and pathogenesis. $J$ Virol $\mathbf{8 9}$ : 8416-8427.

Warren TK, Jordan R, Lo MK, Ray AS, Mackman RL, Soloveva V, Siegel D, Perron M, Bannister R, Hui HC, et al. (2016) Therapeutic efficacy of the small molecule GS5734 against Ebola virus in rhesus monkeys. Nature 531:381-385.

Williamson BN, Feldmann F, Schwarz B, Meade-White K, Porter DP, Schulz J, van Doremalen N, Leighton I, Yinda CK, Perez-Perez L, et al. (2020) Clinical benefit of remdesivir in rhesus macaques infected with SARS-CoV-2. Nature DOI: 10.1038/ s41586-020-2423-5 [published ahead of print]

Wrapp D, Wang N, Corbett KS, Goldsmith JA, Hsieh CL, Abiona O, Graham BS, and McLellan JS (2020) Cryo-EM structure of the 2019-nCoV spike in the prefusion conformation. Science 367:1260-1263.

Xia S, Liu M, Wang C, Xu W, Lan Q, Feng S, Qi F, Bao L, Du L, Liu S, et al. (2020) Inhibition of SARS-CoV-2 (previously $2019-\mathrm{nCoV}$ ) infection by a highly potent pancoronavirus fusion inhibitor targeting its spike protein that harbors a high capacity to mediate membrane fusion. Cell Res 30:343-355.

$\mathrm{Xu}$ J, Shi PY, Li H, and Zhou J (2020a) Broad spectrum antiviral agent niclosamide and its therapeutic potential. ACS Infect Dis 6:909-915.

Xu X, Chen P, Wang J, Feng J, Zhou H, Li X, Zhong W, and Hao P (2020b) Evolution of the novel coronavirus from the ongoing Wuhan outbreak and modeling of its spike protein for risk of human transmission. Sci China Life Sci 63:457-460.

Yang N and Shen HM (2020) Targeting the endocytic pathway and autophagy process as a novel therapeutic strategy in COVID-19. Int J Biol Sci 16:1724-1731.

Yang S, Xu M, Lee EM, Gorshkov K, Shiryaev SA, He S, Sun W, Cheng YS, Hu X, Tharappel AM, et al. (2018) Emetine inhibits Zika and Ebola virus infections through two molecular mechanisms: inhibiting viral replication and decreasing viral entry. Cell Discov 4:31.

Zaim S, Chong JH, Sankaranarayanan V, and Harky A (2020) COVID-19 and multiorgan response. Curr Probl Cardiol 45:100618.

Zaki AM, van Boheemen S, Bestebroer TM, Osterhaus AD, and Fouchier RA (2012) Isolation of a novel coronavirus from a man with pneumonia in Saudi Arabia. N Engl J Med 367:1814-1820.

Zheng W, Sun W, and Simeonov A (2018) Drug repurposing screens and synergistic drug-combinations for infectious diseases. Br J Pharmacol 175:181-191.

Zhou P, Yang XL, Wang XG, Hu B, Zhang L, Zhang W, Si HR, Zhu Y, Li B, Huang CL, et al. (2020) A pneumonia outbreak associated with a new coronavirus of probable bat origin. Nature 579:270-273.

Zhu FC, Li YH, Guan XH, Hou LH, Wang WJ, Li JX, Wu SP, Wang BS, Wang Z, Wang L, et al. (2020) Safety, tolerability, and immunogenicity of a recombinant adenovirus type-5 vectored COVID-19 vaccine: a dose-escalation, open-label, non-randomised, first-in-human trial. Lancet 395:1845-1854

Zumla A, Chan JF, Azhar EI, Hui DS, and Yuen KY (2016) Coronaviruses - drug discovery and therapeutic options. Nat Rev Drug Discov 15:327-347.

Address correspondence to: Dr. Wei Zheng, National Center for Advancing Translational Sciences, National Institutes of Health, 9800 Medical Center Drive, MSC: 3375, Bethesda, MD. E-mail: wzheng@mail.nih.gov 